\title{
Essay
}

\section{The Painting on the Wall}

\author{
Barbara Alfano
}

Isabelle Kaplan Center for Languages and Cultures, Bennington College, One College Drive, Bennington, VT 05201, USA; balfano@bennington.edu; Tel.: +1-802-440-4378

Academic Editor: Patricia Emison

Received: 30 October 2015; Accepted: 18 January 2016; Published: 22 January 2016

\begin{abstract}
This personal essay describes what influenced my development as a creative writer, in my childhood and adolescence. It delineates the effect on my imagination of family story-telling and of images-paintings and prints. I grew up in Italy, where I spent the first thirty years of my life.
\end{abstract}

Keywords: paintings; images; Italy; short story; influence; story telling

I write. That is, I spend a lot of my time carrying out the necessary steps that lead to a scholarly work, most often an essay, or a short story, and then I take it all to the page, my favorite space. ${ }^{1}$

My story as a writer began forty-two years ago. Before I was able to read, the many family anecdotes I was told and the many paintings that surrounded me at home gave direction to my imagination.

Trace in your mind the silhouette of Mount Vesuvius. The peak on the left, lower than the crater, belongs to Mount Somma, or what is left of it after its central part began collapsing twenty-five thousand years ago, and its activity generated the volcano that became the symbol of Naples. I was raised at the foot of the first, older mountain, in the town of Pollena Trocchia, only a twenty-minute train ride from the center of Naples. As a child, I was told that because Mount Somma stands between my town and Vesuvius, the lava never reached us and probably never would. I felt protected.

My father was a Neapolitan, specifically a vomerese: someone who grew up on the hill of Vomero, together with seven brothers and sisters. These details count for Neapolitans. You may not realize how much they count until you find yourself, in your thirties, in line for the bathroom at a Halloween party in State College, Pennsylvania, and you happen to listen to a guy speaking English with an Italian accent. It was a very specific Italian accent, one that carried in its notes a proper, convenient kind of Neapolitan dialect, cleansed of all its working-class tones. How could English sound so much like the Italian spoken in the well-off neighborhoods of Naples, and in Vomero, in particular? I looked at the young man in front of me, scrutinized his reassured, slightly theatrical posture and the angle of his smile, I took in the cadence of his voice and even before saying hi, I asked: "You're from Vomero, aren't you?" He was.

My father too carried with him his Neapolitan soul up to Germany, and later Switzerland, where he lived for a couple of years in his early twenties. He had previously completed a high-school degree in hospitality and hotel management, spoke three languages besides his own, played the guitar, skied and skated, and was ready to conquer the world. His optimism, however, succumbed under the duress of his status as an Italian immigrant in Mitteleuropa. "It wasn't easy for Italians to be accepted, there," he once told me. He was finally shipwrecked in the storm of an impossible love story. She was married, had children, and a brother who was a Catholic priest and who, on the day they should have left together, convinced my father to go back home and live his life without her. My father took the train

1 I am scholar of contemporary Italian literature. In 2013, I published The Mirage of America in Contemporary Italian Literature and Film with the University of Toronto Press. My essays have appeared in Italica, Forum Italicum, Variaciones Borges, and Italian Journal. For my collection of short stories, see the list of references. 
for Italy alone, that same day. His own father went to fetch him at the station. Nonno Franco never asked why Dad was back. According to Dad, the reasons for his return were written in his puffy, sad eyes, and his tired body.

My mother is a pollenese, from Pollena Trocchia, like her mother and her father were, but she grew up not really wanting to be one. The provincialism of the small town scared her. The bombs of WWII and the post-war poverty left her feeling permanently anxious, forever stripped of peace.

After months of eating pea powder dropped in cans from the Allies' aircraft, after being schooled by nuns for fifteen years, and having worn shoes with cardboard soles on a snowy day on her way to the state teachers' license exam, she decided that leaving Naples for her first post as an elementary school teacher up in Piedmont, in the north of the country, was the best thing that could happen to her. The mountainous village she was assigned to, with its one hundred inhabitants and as many sheep, was smaller than any town in the province of Naples she had ever visited, but she loved it.

Yet, like my father, one day she too came back home. She responded to my grandmother's tears. Nonna Carmela wanted her back. Unwillingly, my mother applied for a transfer that, for good reasons, she thought she would never obtain. But she did. It was God's work, said my grandmother, and one does not discuss the will of God. I bear my grandmother's name as my middle name. Like Nonna, I do not question the outcomes of fate. I move along with them.

Mum and Dad were at the beginning of their thirties when they met in the summer of 1966, in a beach town north of Naples. They were good looking, elegant, with big, glittery eyes, slightly tired in spirit, and definitely off track as far as making a family was concerned. They wasted no time. In January 1967, they were married. I was born ten months later and my sister Alessandra, fifteen months after me.

My family told me many stories while I was growing up. Stories of war, stories of poverty, fear, hunger and redemption, pride and stubbornness; meanness, retaliation, and divine justice; lost loves and new beginnings; death, pain, and survival. Soon enough, I realized those tales were not only part of the history of my family, but also of my town and my city. They were to be cherished. More importantly, I developed the acute awareness that life had to be narrated.

I was six and a half when I wrote my first summer composition. It was part of my vacation homework. I was sitting in the kitchen, while my mother was making lunch. There was a bunch of lettuce on the table. A yellow, long worm was crawling on a leaf. I remember the light of the first afternoon coming in from the window behind me. It made the surface of the brown table and the lettuce leaf lucid. I decided instinctively that I would open my composition with the description of that insect's funny, slow movements. That is how I began to narrate the emptiness of my long, summer days, marked at times only by the distant calls of a few street vendors, which I duly reported in my account. I was bored and those minute descriptions were the measure of my tedium. However, my teacher thought that they were the sign of my future as a writer.

I first became a journalist, then an academic who primarily does research on literature, but fiction writing has always been part of who I am.

In those early beginnings of my creative writing, I was describing the world around me, more than telling its story, and I believe this depended mostly on the fact that I was surrounded by paintings, of which I will soon tell.

In my later years of writing, I have certainly never considered description as ancillary to narration. On the contrary, I have always felt that by describing things I was revealing either their own spirit, or the spirit of those from whose perspective I was narrating-this, in and of itself, was part of telling a story. I have come to believe that description must move the story forward as much as the events do. Description reveals, or not; conceals, or not; and by doing so it delineates the path of the story. I open "Uno, due. Tre," or, “One, Two. Three" with a description: 
One two, three four. A black shoe back, one afore. He swayed along the colonnade, eyes down. One, two, three, four ... "Beautiful! This marble streaked with pink is beautiful," he thought. "What a stylish town ... elegant, yes."2. ([1], p. 41)

When I look at the beginning of this short story, I know my imagination as a writer has been influenced by the paintings that surrounded me in our apartment on the outskirts of Naples, while I was growing up. The pictures provided colors and enriched stories.

Zio Federico, my father's brother, was a painter. He painted saturated still-lifes and florid women in ancient costumes carrying their baskets full of groceries through the colorful street markets of Naples. His work hangs in rows on the walls of our home: the sitting room, the corridor, my father's office. Near it, paintings of a local artist, those of my cousin Ciccio, Federico's son, and a couple of attempts by my father himself, like a copy of Filippo Palizzi's "Ciucciariello", ("L'asinello", or "The Little Donkey") as he used to call it.

It wasn't always so. In our old apartment, where I spent most of my childhood and adolescence, pictures were placed on the walls tastefully, strategically hanging in the right places, where they fit. Things changed with time; first, with our move to a smaller apartment where every piece of furniture and décor had to fit, somehow. My parents had seen the war. They had lived through it and had later made sacrifices to buy those timeless pieces of solid wood: they were not going to leave any behind. And, of course, all the paintings would be up on the walls as they were in the old apartment.

My parents' ageing multiplied and solidified the things around them. In that chaotic corner of the world where my family lives, the elderly surround themselves with objects ingrained in their souls. As the space of the living becomes for them more and more the antechamber to the world of the dead, they lose their inclination for elegance, sobriety, and harmony and carelessly fill the room around them with things that bridge their spirits to the spirits of those who have passed on. Or is it their wish to remain on earth for as long as possible, anchored to their knick-knacks by the strength of their stubbornness? Most of these objects, in my family's apartment, are paintings, joined by my father's crafts and photographs, and some prints.

With the years, my parents' rooms in their apartment became more and more an exhibition of their hopes and fears. If my mother added sacred images and plastic Madonnas on which she entwined rosaries of different materials and colors, my father added photos, paper collages, seashells, stones, airplanes, cardboard guitars and music speakers he made himself, real guitars, birds assembled with metal scraps, fitness gear, music scores, and more paintings. Like the sacred images, these too had a salvific function. My mother trusted God and his emissaries, my father art, artifacts, and beauty. Of God, he would only write. After his death, I found proof of his deep spirituality in notes written here and there to himself.

Paintings, of course, were not only at home. The frescoes in my small-town church became part of my writing as well. In that church, "La cresima", or "Confirmation", takes place [2]. Its protagonists, for one reason or another, all look up at the same ceiling I used to stare at during mass. There, amidst the fishers' nets, Jesus invites Peter to follow him.

At home, I enjoyed each painting in its own right, but I never liked the array of canvases, framed in thick wood and placed on the wall, gallery-style. "Too much, Dad, this is too much." Dad looked at me with disappointment and a hint of anger at the corner of his mouth, "Why? I' m not taking anything down. Forget it."

Regardless of my dislike for how my father arranged paintings on the wall, I believe those images, whether hanging in the bigger and more stylish home of my childhood, or in the smaller apartment of the later years, influenced my writing and my way of organizing space on the page and around me.

2 “Un due, tre quattro, un piede nero davanti all'altro. Ciondolava lungo i portici a testa bassa. Un due, tre quattr ... 'Bello questo marmo striato di rosa' pensava, 'che città elegante ... Elegante, sì."'All the translations from Italian to English in this essay are mine. 
I learned that emptiness was essential, that shapes needed to support one another, and colors had to talk to each other nicely. I sought harmony in all aspects of expression.

Sometimes, objects from those pictures would pop up in my writing, like a Ford Model A, whose print was first in the old dining room and later in my father's studio:

One two, three four-Via Trezza 38. Here time dissolved every night. In the courtyard of the sixteenth-century building, a cloudy lamp alone remained lit to give silence some body. One could imagine a corpse carrier, exuding black death, pushing his load on the other side of the portal; or a buggy and its driver, with his overcoat and top hat ... maybe a hooting Ford Model A, or still yet a stomping squadron of black shirts. For those who might have been inside, under the light of silence, beyond the portal it could have been any of the evenings passed in the enlightened life of the Western world. That evening, the door opened onto darkness troubled by wind. A freezing gust pushed two men inside at the end of the millennium. ([1], p. 66). ${ }^{3}$

One never knows what surfaces from the cauldron of memory and becomes a streak of color on the page, as happened with my Ford Model A.

Although the beginning of "À Paris" is a fairly honest representation of what I saw and how I felt there, I suspect that what led me to Paris and filled my mind with a certain atmosphere, as I wrote the story, was a print of the city's cafès under the rain—what else?-with the Eiffel Tower lurking in the distance:

À Paris ... It was cold in July. It rained. La tour Eiffel was a big toy planted with no taste in the middle of the city; I had sought its peak in the sky for an entire morning, with no success. I finally discovered the monument bottom to top while folded over and intent on gluing a broken shoe. I saw one of its enormous feet appear in the trees on my left, like Gulliver's boot in Liliput, and this made me laugh. ([3], p. 85) ${ }^{4}$

The joy I found under the rain in Paris, and later described in my short story, began with that gray print drizzled with red, yellow, and green.

I believe that the vibrant, nineteenth-century women of my uncle's canvases allowed me to experiment with color as an adolescent. Their long, voluminous skirts were usually painted in bright red, orange, deep azure, gold, and pink. A low black corset separated the skirts from the large, white shirts whose sleeves were folded up. A bright scarf loosely kept together their untidy hair, and big, round, golden earrings framed their happy faces. Those women were always smiling, joyfully carrying their baskets of fruit, the colors of which were too vivid to be realistic. In middle school, my art teacher wrote in her evaluation of my work that, although I was not particularly keen on drawing, I had "uno spiccato gusto coloristico," "a pronounced taste for colors." I loved colors, but I could not use them on myself until I was old enough to tell my mother: "No! I don't care what you like. I'll do as I please."

As a child, I wore what my mother told me to, and my mother's preoccupation, just like all Italian mothers', was for us children to be well-dressed; fashionable, yes, but sober. The diplomatic art of convincing a child to choose tamer, and matching, colors in the morning is one in which Italian mothers should get a degree ad honorem. With the only exception of the day when she inadvertently sent us to

3 “Un due, tre quattro ... Via Trezza, 38-qui il tempo si scioglieva ogni notte. Nel cortile del palazzo secentesco restava una lucerna opaca a dare corpo al silenzio; al di là del portone sarebbe potuto passare un monatto puzzolente di morte, oppure un calesse col il cocchiere in tuba e pastrano ... forse una Ford strombettante modello A, o uno squadrone di fasci ... per chi si fosse trovato dentro, alla luce del silenzio, dall'altra parte avrebbe potuto essere una sera qualunque della vita illuminata d'Occidente. Quella notte il portone si aprì su un buio pesto agitato dal vento e una folata gelida sospinse nell'androne due uomini di fine millennio."

4 "À Paris ... a luglio faceva freddo. Pioveva. La Tour Eiffel era un giocattolone piazzato senza gusto in mezzo alla città, lo scoprii dal basso in alto, mentre piegata incollavo una scarpa rotta. Per un'intera mattinata avevo cercato con lo sguardo la vetta della Torre, senza trovarla. Ne vide un piede, enorme, spuntare tra gli alberi alla mia sinistra come lo stivale di Gulliver a Liliput, e mi venne da ridere." 
kindergarten in slippers, my mother was always very careful about what my sister and I wore. She knew that what we looked like revealed what kind of mother she was. I still see her driving after the school bus and catching us, as we got off, to have us put on our shoes. She was late to school that day-she was a teacher-but she made sure we would go to class in proper attire.

The children of my generation were not allowed to give in to self-expression when it came to dressing. I took my revenge, then, on my mother's browns, beiges, and pastel hues when I was an adolescent. The seventies had left us, at last. My hair had finally grown, in spite of my mother's attempts to keep it short, and the eighties had arrived. For a few months, I left home in the morning wearing metallic green eye shadow, a Barbie-pink sweatshirt, and a lemon yellow, lacy scarf. "E.T." was my classmates' comment. I was proud of my colors and for years, although with softer hues, I kept being colorful. So were the short stories I was writing in every free minute I had. If I think of those colors, I see them all in the images that were surrounding me as a child in my home.

As I grew up and I abandoned flashy tones-"chiassosi" is the Italian adjective-I retained my desire to let color prevail.

In my own house, everything is evidence of what I have internalized, accepted, or refused while looking at the paintings in my Italian homes: the way in which I chose the colors, beginning with the walls, and the way in which I calibrated the distances between objects, built emptiness into the geometry, chose the frames of the only two paintings I own. The silver of the vase on the dresser, the orange and burgundy of the cacti that I repotted in a wooden salad bowl because its roundness refers to the wavy bluish-grey drawer underneath, and the position of the plants that I picked out carefully to match the style of the furniture nearby: all began with an image in my mind.

The closing paragraph of "One, Two. Three" was inspired by a wooden bas-relief that my father bought in the nineties. A woman in black, half-undressed, is lying lazily on a long chair by a small table on which a big, green apple is set. Her eyes are covered by a long red drape coming down from a large hat on her head. She holds between her turgid lips an edge of that red cloth. She is pulling up her long black gown, uncovering black stockings and naked thighs. Her body is an indolent object of desire. That sensation of abandonment and idleness led me to write:

One, two. Three. Once in the room, he did not turn on the light. He brushed against the furniture's dark silhouette, turned an armchair towards the moon and sat comfortably to observe black clouds parade slowly to salute with their shade the yellow matron-indolent caresses between strangers of the same sky, never again so close. ([1], p. 82). ${ }^{5}$

Wherever I was turning my head, as a child and a young adult, there was a painting on the wall. That painting has been part of how I embraced writing.

\section{References}

1. Barbara Alfano. “Un, due. Tre.” In Mi chiedevo. Lecce: Manni, 2009, pp. 41-82.

2. Barbara Alfano. "La cresima.” In Mi chiedevo. Lecce: Manni, 2009, pp. 13-19.

3. Barbara Alfano. “À Paris.” In Mi chiedevo. Lecce: Manni, 2009, pp. 85-91.

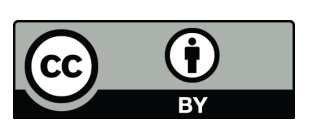

(C) 2016 by the author; licensee MDPI, Basel, Switzerland. This article is an open access article distributed under the terms and conditions of the Creative Commons by Attribution (CC-BY) license (http:/ / creativecommons.org/licenses/by/4.0/).

5 “Un, due. Tre. In camera non accese la luce; sfiorò i profili scuri dei mobili, voltò una poltrona verso la luna e si accomodò ad osservare nuvole nere di passaggio che sfilavano lente e disordinate a salutare d'ombra la matrona gialla, carezze indolenti fra estranei dello stesso cielo mai più così vicini." 